\title{
Gıdalarda pH Ölçümünün Önemi
}

\author{
Asli $\mathrm{AKSOY}^{1 *}$ \\ ${ }^{1}$ Haliç Üniversitesi, Güzel Sanatlar Fakültesi, Gastronomi ve Mutfak Sanatları \\ Bölümü, İstanbul, Türkiye
}

Orcid: 0000-0002-7775-6514.

*Sorumlu Yazar e mail: asliaksoy@halic.edu.tr

Geliş Tarihi: 04.08 .2021

Kabul Tarihi: 27.08 .2021

Atıf/Citation: Aksoy, A., "Gıdalarda pH Ölçümünün Önemi”, Haliç Üniversitesi Fen Bilimleri Dergisi 2021, 4/2: 193-216.

Derleme Makaleler/ Review Articles

\section{Özet}

Gıda güvenliği ve kalitesinin sağlanması için gerek hammadde gerekse son ürün üzerinde çeşitli analizler yapılmaktadır. Asitlik, gıdalardaki önemli kalite kriterlerinden biridir. Asitlik ölçümü için kullanılan en genel ve pratik tekniklerden biri pH ölçümüdür. pH; hammadde, yarı mamul ya da son ürün kalite kontrolü ve ürün mikrobiyal güvenliğinin incelenmesi sırasında kullanılan parametrelerden biridir. Her gıdanın sahip olduğu belirli pH değerleri mevcuttur. $\mathrm{Bu} \mathrm{pH}$ değerlerinden sapma olduğunda, ürünle ya da prosesle ilgili bir sorun olduğu kabul edilmektedir. Bu çalışmada gıdalarda pH ölçümünün öneminin değişik açılardan ele alınması, ürün standartları ile mevzuat açısından irdelenmesi ve geniş kapsamlı bir derleme hazırlanarak literatür ve gıda sektörüne bilgi sağlanması amaçlanmıştır. Bu doğrultuda bazı gıdaların pH değerleri verilmiş; mevzuat ve standartlar açısından, kalite kriteri olarak pH ölçümü yapılması gereken ürünler listelenmiştir. Gıdalara uygulanan fermantasyon, konserveleme, muhafaza ve marinasyon gibi işlem aşamalarında gerçekleştirilen $\mathrm{pH}$ ölçüm sonuçlarının, ortaya çıkacak son ürünün çeşitli özellikleri hakkında ip ucu verebileceği hususuna değinilmiştir. Ayrıca et, süt, sebze, meyve ve bunların çeşitli ürünleri, fırıncılık ürünleri, balık yetiştiriciliği suları ve gıda dezenfektanları gibi ürünlerin, kalite ve gıda güvenliği açısından; bozulma, tazelik, doku, renk, aroma, olgunlaşma gibi özellikleri ile pH değerleri arasındaki ilişki açıklanarak, gidalarda $\mathrm{pH}$ ölçümünün öneminden bahsedilmiştir.

Anahtar Kelimeler: pH, Asitlik, Gıda, Kalite, Gıda güvenliği. 


\title{
The Importance of pH Measurement in Foods
}

\begin{abstract}
Various analyses are carried out on both raw materials and final products to ensure food safety and quality. Acidity is one of the important quality criterias in food. One of the most common and practical techniques used for acidity measurement is $\mathrm{pH}$ measurement. $\mathrm{pH}$ is one of the parameters used during raw material, semi-finished or final product quality control and product microbial safety examination. Each food has different $\mathrm{pH}$ values. Any deviation from these $\mathrm{pH}$ values is considered to be a problem with the product or process. In this study, it is aimed to evaluate the importance of $\mathrm{pH}$ measurement in foods from different perspectives, to examine product standards and legislation, and to provide knowledge to the literature and food industry by preparing a comprehensive review. In this context, $\mathrm{pH}$ values of some foods are given; in terms of legislation and standards, products for which $\mathrm{pH}$ should be measured as quality criteria are listed. It was mentioned that the $\mathrm{pH}$ measurement results obtained during the processes such as fermentation, canning, preservation and marination applied on foods may give clues about the various properties of the final product. In addition, for quality and food safety, the importance of $\mathrm{pH}$ measurement has been mentioned by explaining the relationship between the $\mathrm{pH}$ values of products such as meat, milk, vegetables, fruits and their various products, bakery products, fish farming waters and food disinfectants, and the properties such as spoilage, freshness, texture, color, flavor and ripening.
\end{abstract}

Keywords: pH, Acidity, Food, Quality, Food safety.

\section{Giriş}

Tüketicilerin yüksek kaliteli, minimum düzeyde işlenmiş, katkısız, raf ömrü uzun, kullanışlı ve güvenli gıda ürünleri talebini karşılamak için gıda endüstrisinde yoğun çalışmalar yapılmaktadır [1]. Dolayısıyla çiftlikten çatala, tarladan tabağa kadar, bir gıda hammaddesinin son ürün haline dönüşene dek geçirdiği her aşamada gerekli analizlerin yapılarak, kalite ve gida güvenliği kriterlerinin sağlanması gerekmektedir. Bu amaçla bir gıdanın ya da hammaddesinin toplam asitlik ve alkalilik özelliklerinin saptanması, temel uygulamalar arasında önemli bir yere sahiptir. Bir üründeki toplam hidrojen iyonu $\left(\mathrm{H}^{+}\right)$ 
konsantrasyonunun, kuvvetli bir baz ile titre edilebilirliğinin ölçüsü "toplam asitlik" olarak adlandırılmaktadır [2]. "Alkalilik" ya da "alkalinite" kavramı ise, bir asidi nötrleme özelliği şeklinde tanımlanmaktadir [3].

G1da sektöründe kalite kriteri olarak daha çok "asitlik" kavramı önemlidir. Bazı gıda proseslerinde son ürün ya da hammadde kalitesinin değerlendirilmesi, uygulanacak işlem ve şartlarının netleştirilmesi ve proses basamaklarının izlenebilmesi için asitlik tayini gerçekleştirilmektedir. Asitliğin belirlenmesi için ise, $\mathrm{pH}$ ölçümü ya da titrasyon asitliği analizi yapılmaktadır [4]. pH ölçümü için genelde potansiyometrik ölçüm esasına dayanan $\mathrm{pH}$ metreler kullanılırken, asitliğin saptanması için titrasyon uygulaması yapılmaktadır [5].

Latince "pondus hydrogenii" (pondus= basınç, hidrogenyum= hidrojen) ifadesinin kısaltması olan pH [6], en genel anlamda bir ürünün asitliğinin derecesi olarak ifade edilmektedir [5]. Ayrıca pH, Eşitlik 1'de belirtildiği gibi hidrojen iyon konsantrasyonunun negatif logaritması olarak tanımlanmaktadır $[7,8]$.

$$
\mathrm{pH}=-\log \left[\mathrm{H}^{+}\right]
$$

Suda $\mathrm{H}^{+}$ve $\mathrm{OH}^{-}$(hidroksil) iyonları konsantrasyonu (her ikisi de $\left.1 \times 10^{-7} \mathrm{~mol} / \mathrm{L}\right)$ birbirine eşittir.

$$
\mathrm{H}_{2} \mathrm{O} \Leftrightarrow \mathrm{H}^{+}+\mathrm{OH}^{-}
$$

Bu iyonlaşma, suyun diğer çözünmüş maddeler tarafından ihtiyaç duyulduğunda $\mathrm{H}^{+}$iyonları vermesini veya almasını sağladığı için sulu çözeltilerin kimyasında büyük önem taşımaktadır. Eşitlik 2'ye kütle etkisi yasası uygulandığında, Eşitlik 3 elde edilmektedir.

$$
\left[\mathrm{H}^{+}\right]\left[\mathrm{OH}^{-}\right] /\left[\mathrm{H}_{2} \mathrm{O}\right]=\text { sabit }
$$


Saf su ve seyreltik çözeltilerde, iyonlarına ayrışmamış suyun konsantrasyonu sabit $\left(\mathrm{K}_{\mathrm{s}}=\right.$ suyun iyonik ürünü olarak adlandırılan bir sabit) (Eşitlik 4) kabul edilmektedir.

$$
\left[\mathrm{H}^{+}\right]\left[\mathrm{OH}^{-}\right]=\mathrm{K}_{\mathrm{s}}
$$

İyonlaşma, sıcaklığa bağlı olarak değişmektedir. Ancak yaklaşık $25^{\circ} \mathrm{C}^{\prime}$ de değeri $10^{-14} \mathrm{~mol}^{2} \cdot \mathrm{dm}^{-6}$ dır $\left(\mathrm{K}_{\mathrm{s}}\left(0^{\circ} \mathrm{C}\right)=10^{-14.9}, \mathrm{~K}_{\mathrm{s}}\left(25^{\circ} \mathrm{C}\right)=10^{-}\right.$ $\left.{ }^{14.0}, \mathrm{~K}_{\mathrm{s}}\left(60^{\circ} \mathrm{C}\right)=10^{-13.0}\right)$. Bu, saf suda iyonlaşmanın çok az gerçekleştiği anlamına gelmektedir. Saf suda, $\mathrm{H}^{+}$ve $\mathrm{OH}^{-}$iyonlarının konsantrasyonları eşittir $\left(25^{\circ} \mathrm{C}^{\prime} \mathrm{de}[\mathrm{H}+][\mathrm{OH}-]=10^{-14} \mathrm{~mol}^{2} \cdot \mathrm{dm}^{-6}\right.$ olduğundan $\left[\mathrm{H}^{+}\right]$(ya da $\left.\left[\mathrm{OH}^{-}\right]\right)=10^{-7}$ mol.dm ${ }^{-3}$ 'tür). Kesin olarak doğru olması için, eşitlik (2), aşağıda yer alan Eşitlik (5) gibi yazılmalıdır [7].

$$
2 \mathrm{H}_{2} \mathrm{O} \Leftrightarrow \mathrm{H}_{3} \mathrm{O}^{+}+\mathrm{OH}^{-}
$$

pH değerleri 0-14 aralığındadır. Saf suyun pH değeri $7\left(\mathrm{H}^{+}\right.$ve $\mathrm{OH}^{-}$ iyonlarının sayıları eşit) olduğundan, pH 7 “nötr” olarak, pH 7'nin altındaki değerler (ortamda $\mathrm{H}^{+}$iyonları sayısı fazla olduğunda) "asidik", pH 7'den büyük olanlar (ortamda $\mathrm{OH}^{-}$iyonları sayısı fazla olduğunda) ise "bazik (alkali)" olarak kabul edilmektedir [1, 7].

Bir gıdanın pH değeri, o gıdanın içerdiği serbest hidrojen iyonlarının doğrudan bir fonksiyonudur. Gidalarda mevcut bulunan ve g1daya farklı ekşi tatları veren asitler, hidrojen iyonlarını serbest bırakarak dissosiye olmaktadır. Bu nedenle $\mathrm{pH}$, bir serbest asitlik (aktüel asitlik) ölçüsü olarak tanımlanabilmektedir [1]. Dolayısıyla gıdaların pH'ının ölçülmesinde kullanılacak ekipman ve metotlar, sonucun doğruluğu, kesinliği ve hassasiyeti için oldukça önemlidir [9]. Geleneksel olarak pH ölçümü, ortamdaki hidrojen iyonuna $\left(\mathrm{H}^{+}\right)$karşı duyarlı bir cam elektrot, bir referans elektrot (hidrojen, kinhidron, antimon ve bizmut) ve yüksek empedans girişi içeren $\mathrm{pH}$ metreler yardımıyla gerçekleştirilmektedir $[6,10,11,12]$. Referans elektrot, ortamdaki hidrojen iyonu konsantrasyonuna göre elektrik akımı sağlayarak, ölçüm yapılmasına olanak sağlamaktadır [11]. Ayrıca pH ölçümü için çeşitli 
alternatif yöntemler ve cihazlar da (renk indikatörü $\mathrm{pH}$ çubukları, fotometreler vb. gibi) mevcuttur. Ancak mevcut yöntemlerin ve cihazların pratik kullanımı çoğunlukla atmosferik basınç pH ölçümü ile sınır1ıdır $[6,10]$. Örneğin yüksek basınçlı sistemlerde $\mathrm{pH}$ ölçümü için cam elektrot tertibatlarının kullanımı, camın kırılgan olması nedeniyle uygun değildir [10]. Bu gibi nedenlerle piyasada sektörün ihtiyaçlarına göre kırılgan cam yerine silikon mikroçipten oluşan yarı iletken teknolojisini kullanan ISFET (iyon duyarlı alan etkili transistör, "ion-sensitive field-effect transistor") $\mathrm{pH}$ sensörleri de mevcuttur. Ancak bu sensörlerden gelen sinyaller, standart $\mathrm{pH}$ ölçerlerle analiz edilememektedirler [6, 13]. Dolayısıyla gıdanın yapısı ve ölçüm ortamı baz alınarak, $\mathrm{pH}$ ölçümü gerçekleştirilmelidir.

$\mathrm{Bu}$ çalışmanın amacı $\mathrm{pH}$ 'ın gıdalar açısından öneminin geniş bir perspektifle irdelenmesi, gıda çeşidi bazında literatür çalışmalarında, standartlarda (TS: Türk Standardı) ve mevzuatta (Türk Gıda Kodeksi ilgili ürün tebliğleri) belirtilen limit değerlerin derlenmesi ve geniş kapsamlı bir araştırma yapılarak gıda sektörüne ve literatüre bir kaynak oluşturulmasıdır.

\section{Gıda ve pH Değerleri}

Gıdanın yapısındaki bileşenler arasında biyokimyasal etkileşimler (denatürasyon, jelatinizasyon, enzimatik ve Maillard reaksiyonu gibi enzimatik olmayan reaksiyonlar, mikrobiyal faaliyet, renk, aroma ve yapısal değişiklikler vb.) söz konusudur [1, 14]. Bu etkileşimlerden faydalanılarak bir gıda hammaddesinin ya da son ürünün $\mathrm{pH}$ gibi kriterlerindeki değişimin ölçülmesi, gıdanın güvenliği ve kalitesi hakkında önemli ve belli ölçülerde bilgi sağlayabilmektedir [1]. Eğer ürün formülasyonuna göre eklenen herhangi bir maddeden dolayı ürünün pH'nın artması ya da azalma durumu söz konusu değilse, gıdaların genel olarak sahip olduğu kabul edilen pH değerlerinin (Tablo 1-7) dişına çıkması, ürün kalitesinde sorun olduğu konusunda fikir verebilir. Şekil 1 'de bazı gıdaların pH skalasına göre gruplandırılması gösterilmiştir. 
4 Turşu, sirke, peynir, pasta, şarap, domuz eti, çikolata, kavrulmuş fındık

5 Saf su, kahve, sığır eti, beyaz ekmek, yer fıstığı, fındık, buğday

6 Meyve suları, tam tahıllar, karaciğer, yumurta, balık, istiridye, soya sütü, Hindistan cevizi, arpa, yulaf.

Şekil 1: Bazı gıdaların pH skalasına göre gruplandırılmas1 [15]

Mikrobiyal bozulmayı (özellikle bakteri kaynaklı) belirlemek için klasik yöntemler dışında, polimeraz zincir reaksiyonu (PCR, "Polymerase Chain Reaction"), enzime bağlı immünolojik test (ELISA, "Enzyme-Linked ImmunoSorbent Assay") ve DNA/RNA hibridizasyonu gibi modern yöntemlerden de yararlanılmaktadır. Ancak bu yöntemler zaman alıcı, hacimli ve pahalı olmaları nedeniyle, portatif tüketici uygulamaları için uygun değildirler. Minyatürleştirilmiş elektrokimyasal biyosensörler, bakteri tespiti için umut verici olarak görülmektedir. Bunların arasında potansiyometrik sensörler, $\mathrm{pH}$ algılama yoluyla bakteri konsantrasyon bilgilerini voltaja dönüştürebilmektedir. Bakterilerin metabolik mekanizması nedeniyle, üretilen asetat, laktat ve süksinat gibi asidik maddeler, kültür ortamının iyonik bileşimini değiştirmektedir. Belli bir ortam hacmi için, bakteri konsantrasyonu ne kadar yüksek olursa, asitlik oranı o kadar yüksek olmakta ve daha büyük bir pH değişikliğine yol açmaktadır. Bu nedenle, ortam pH farkını tespit ederek, bakteri konsantrasyonun ölçülmesi mümkündür. $\mathrm{pH}$ değerindeki 0.01'lik küçük bir değişiklik, gıda hijyeni açısından önemlidir [13].

pH değeri ile birçok gıdanın çeşitli özellikleri tahmin edilebilmektedir. Örneğin meyvenin tazeliği veya şarabın tadının tatlılık ya 
da acılığı gibi özellikler, et ve sosis gibi et ürünlerinin olgunlaşması, $\mathrm{pH}$ değerinin izlenmesi ile anlaş1labilmektedir $[6,16]$. Bu örnekleri çeşitlendirmek mümkündür. Aşağıdaki başlıklar altında bazı ürünler için $\mathrm{pH}$ 'in öneminden bahsedilmiştir.

\subsection{Meyve - Sebze ve pH Değerleri}

Hasat sonrası tarladan sofraya dağıtım sırasında, taze meyve ürünlerinin zarar görmesi veya kullanıma elverişsiz olması nedeniyle, kalite kayıplarını önlemek için kalite takibi amacıyla klasik olarak sıcaklık ve nem gibi ortam koşulları sürekli izlenmektedir. Ancak meyvelerin kalitesi hakkında bu parametreler sadece dolaylı olarak bilgi sağlamakta, meyvelerin olgunlaşma durumu gibi diğer özellikler hakkında bilgi vermemektedir. Olgunlaşma, yeşil meyvenin oldukça lezzetli, besleyici ve renkli meyveye dönüştürüldüğü önemli bir aşamadır. Örneğin üzüm gibi meyvelerin olgunluğunun saptanmasında $\mathrm{pH}$ değişikliği yoluyla olgunlaşma değerlendirilebilmektedir. Çünkü olgunlaşma aşamalarında uçucu organik asit miktarına bağlı olarak pH değerleri de değişmektedir [17].

Olgunlaşma dişında, meyvelerin kimyasallarla muamele edilip edilmediği konusunda da $\mathrm{pH}$ ölçümünden yararlanılabilmektedir. Formalin, gidaların (özellikle meyveler) daha uzun süre taze görünmesini sağlamak için sıklıkla kullanılan, çevre ve insan sağlı̆̆ı üzerinde toksik etkilere sahip olan organik kimyasal bir maddedir. Formaldehit ve sudan oluşan bu madde, belirgin bir $\mathrm{pH}$ karakteristiğine sahiptir. Meyvelerdeki formalini, çözeltinin pH'ına göre çıkış voltajı veren bir pH sensörü kullanarak tespit etmek mümkündür [18].

Ayrıca gıda tazeliğinin gerçek zamanlı izlenmesi için yenilebilir malzemelere dayanan geliştirilmiş kolorimetrik $\mathrm{pH}$ sensörü filmler de söz konusudur. Ahmad ve ark. [19] tarafından deniz ürünleri üzerinde yapılan bir çalışmada, yenilebilir bitkiler Clitoria $s p$. ve Brassica $s p$.'den elde edilen karışık doğal boyaların karagenan filme uygulanmasıyla elde edilen kolorimetrik $\mathrm{pH}$ sensörü geliştirilmiş ve başarıyla uygulanmıştır. 
Meyve-sebze suyu teknolojisinde $\mathrm{pH}$ kontrolü, ürüne durultma yapılması sırasında da önemli bir parametredir. Ayrıca jelatinizasyon (marmelat, reçel, ya da jöle yapımı gibi) işleminin takibi için pH ölçümü önemlidir [20]. Örneğin kristallenmenin önlenmesi için, ürüne sitrik asit eklenerek pH 2.8 civarına düşürülmektedir. $\mathrm{pH}$ 'ın bu değerlerde olmaması, pektin ve asit yetersizliği sonucu iyi bir jelatinizasyon yapılamayacağının göstergesidir [21]. Tablo 1'de bazı meyve ve sebzelerin sahip olduğu $\mathrm{pH}$ değerleri özetlenmiștir.

Tablo 1. Bazı meyve ve sebzelerin sahip olduğu pH değerleri [22].

\begin{tabular}{llll}
\hline Ürün & $\mathbf{p H}$ & Ürün & $\mathbf{p H}$ \\
\hline Çeşitli sebzeler & & & \\
\hline Brüksel lahanası & $6.0-6.3$ & Havuç suyu & 6.4 \\
Bezelye (dondurulmuş) & $6.4-6.7$ & Havuç (taze) & $4.9-5.2$ \\
Bezelye (konserve) & $5.7-6.0$ & Ispanak (pişmiş) & $6.6-7.2$ \\
Bezelye (kurutulmuş) & $6.5-6.8$ & Ispanak (taze) & $5.5-6.8$ \\
Bezelye (taze) & $5.8-7.0$ & Lahana (taze) & $5.2-6.0$ \\
Domates (taze) & $4.2-4.9$ & Mantar (pişmiş) & 6.0 \\
Domates salçası (konserve) & $3.5-4.0$ & Maydanoz & $5.7-6.0$ \\
\hline Çeşitli meyveler & & & \\
\hline Çilek (dondurulmuş) & $2.3-3.0$ & Kayısı (kurutulmuş) & $3.6-4.0$ \\
Çilek (taze) & $3.0-3.5$ & Kayısı (taze) & $3.3-4.0$ \\
Elma (kırmızı, taze) & 3.9 & Limon suyu (konserve) & 2.3 \\
Elma suyu & $3.4-4.0$ & Limon (taze) & $2.2-2.4$ \\
Greyfurt suyu & 3.0 & Mango & $3.9-4.6$ \\
Greyfurt (taze) & $3.0-3.3$ & Portakal suyu & $3.6-4.3$ \\
Hurma & $6.3-6.6$ & Portakal (taze) & $3.1-4.1$ \\
Karpuz & $5.2-5.8$ & Üzüm & $3.4-4.5$ \\
\hline
\end{tabular}




\subsection{Hayvansal Kaynaklı Gıdalar ve pH Değerleri}

Hayvansal kaynaklı gıdalardan et ve deniz ürünleri, süt ve süt ürünleri ve yumurta ve yumurta ürünleri açısından $\mathrm{pH}$ önemli bir kalite ve gida güvenliği kriteridir.

\subsubsection{Et, deniz ürünleri ve pH Değerleri}

Bazı gıdalar için protein ekstraksiyonu ve denatürasyon derecelerinin saptanması için asitlik ölçümü yapılmaktadır. Çünkü proteinlerin çöktügü ve çözündüğü $\mathrm{pH}$ değerleri bilindiği takdirde, asitlik bu pH aralığına ayarlanabilmektedir [20]. Bu özellik en fazla et ürünleri için önemlidir. Et ve et ürünlerinin pH'1 4.5-6.0 arasında değişmektedir. Et endüstrisinde, kesimden sonraki pH'taki düşüşe göre DFD ("darkfirm-dry"/koyu-sert-kuru) eti, normal et ve PSE eti ("pale-soft-exudative"/soluk-yumuşak-sulu) olmak üzere üç farklı et türü kullanılmaktadır. Şekil 2'de, kesimden sonra farklı et türlerinin $\mathrm{pH}$ eğrileri gösterilmiştir [6].

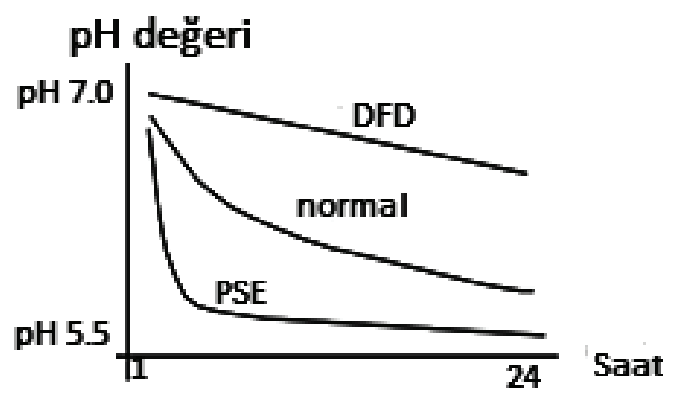

Şekil 2. Kesimden sonra farklı et türlerinin pH eğrileri [6]

Şekil 2'den de görülebileceği gibi DFD etin pH'1 çok yavaş, PSE etinin $\mathrm{pH}$ 'ı ise nispeten hılı düşmektedir. pH'ın düşüş hızı, etin belirli işleme prosesleri için uygunluğunun göstergesi olabilmektedir. Örneğin PSE eti, yüksek kuruma kayıpları ve soluk renginden dolayı çĭg jambon üretimine uygun değildir [6]. 
Özellikle sucuk sosis gibi ürünlerin üretiminde hammadde olarak kullanılacak etlerin işlenebilirlik, verim ve maliyet açısından su tutma kapasitesinin yüksek olması istenmektedir. Su tutma kapasitesi, etin doğal olarak barındırdığı suyu yapısında tutabilme kabiliyetidir [23]. pH'1 7'ye yakın olan etlerde proteinlerin su tutma kapasitesi yüksektir. Dolayısıyla ham etin kalite kontrolünde, $\mathrm{pH}$ önemli bir kriterdir [20]. Kasın ete dönüşmesi sırasında, dokuda laktik asit birikerek etin $\mathrm{pH}$ değerinde bir azalmaya yol açmaktadır. $\mathrm{pH}$ değeri, başlıca proteinlerin, özellikle miyozinin ( $\mathrm{pI}=5.4)$ izoelektrik noktasına $(\mathrm{pI})$ ulaştığında, proteinin net yükü "sıfır" olmakta, yani proteinler üzerindeki pozitif ve negatif yüklerin sayıları eşitlenmektedir. Kesim sonrası pH’taki bu düşüşün yanı sıra, proteoliz ve protein oksidasyonu da etin su tutma kapasitesini etkilemektedir [24].

Salam ve sosis gibi emülsifiye et ürünlerinde, su ve yağ bağlama kapasitesini, dolayısıyla emülsiyon kapasitesini arttırmak amaciyla uygun gıda katkı maddeleri (emülsifiyerler) kullanılarak pH'ın yükseltilmesi sağlanmaktadır. Pastırma ve sucuk gibi ürünlerin kurutulması gibi bazı durumlarda, ürün pH'ı düşürülerek etin su tutma kapasitesi azaltılmakta ve kuruma süresinin kısaltılması sağlanabilmektedir [20].

Etlerde ölçüm için kullanılan $\mathrm{pH}$ elektrodu, protein kontaminasyonuna karşı hassas olmamalıdır. Aksi takdirde elektrodun ömrü ve reaksiyon süresi çok hızlı bir şekilde azalmaktadır. Günümüzde et endüstrisinde kullanımı pratik çeşitli ekipmanlar mevcuttur [6].

$\mathrm{pH}$ faktörü, etlerin marinasyon prosesi için de oldukça önemlidir. Marinasyon asidik ya da bazik olarak uygulanabilmektedir. Daha çok asidik marinasyon tercih edilmekte olup, bu amaçla organik asit çözeltileri, sirke, şarap ve meyve sularından yararlanılmaktadır [25]. Marine edilen etlerin $\mathrm{pH}^{\prime} 1$ genelde düşmektedir. $\mathrm{Bu} \mathrm{pH}$ düşüşü, etin daha parlak görünerek albenisini artırırken, özellikle pH 6'nın (izoelektrik nokta) altına düştüğünde, proteaz aktivitesi sonucu [26] protein hidrolizasyonu ve kolajenin çözünmesini gerçekleşmekte, sululuk ve yumuşaklık gibi etin duyusal özelliklerini geliştirerek ürüne değer katmaktadır $[1,27,28,29,30]$. pH 5.8-6.3 arasında ise et sertliğinin 
artabildiği belirtilmektedir [26]. Aynı zamanda marinasyon ile pişirme kayıplarının da önüne geçilebilmektedir [1]. Bazı et çeşitlerinin sahip olduğu pH değerleri, Tablo 2'de verilmiştir.

Tablo 2. Bazı et çeşitlerinin sahip olduğu pH değerleri [22, 31, 32, 33, 34].

\begin{tabular}{llll}
\hline Ürün & $\mathbf{p H}$ & Ürün & $\mathbf{p H}$ \\
\hline Çeşitli et ürünleri & & & \\
\hline Domuz eti & $5.3-6.9$ & Siğır eti (konserve) & 5.8 \\
Jambon & $5.9-6.1$ & Siğır eti (olgunlaşmış) & 7.0 \\
Kuzu eti & $5.4-6.7$ & Sığır eti (olgunlaşmamış) & $5.9-6.1$ \\
Siğır eti (çekilmiş) & 6.6 & Tavuk eti & $6.5-6.7$ \\
Fermente sucuk & $5.4-5.8$ & Pastırma & $4.5-5.8$ \\
\hline Çeşitli balık ve deniz ürünleri & & \\
\hline Hamsi & 6.77 & Ringa balığ & $6.1-6.4$ \\
İstiridye & $4.8-6.3$ & Somon & $6.1-6.3$ \\
Karides & $6.8-7.0$ & Tatlı su balığı & $6.9-7.3$ \\
Mersin balığ1 & $5.5-6.0$ & Ton balığ1 & $5.2-6.1$ \\
Palamut & $5.41-5.66$ & Yengeç & 7.0 \\
\hline
\end{tabular}

\subsubsection{Süt ürünleri ve pH Değerleri}

Çiğ sütün pH'1 6.4-6.8 arasında değişmektedir [35]. Sağımı yeni yap1lan süt asidik reaksiyon (ilk asitlik) göstermektedir. Ancak bu özelliği zamanla azalmaktadır. Bekleme süresi ve sağım koşullarına bağlı olarak mikroorganizmalarla kontamine olabilmekte ve mikroorganizma (laktik asit bakterileri gibi) faaliyeti sonucu laktozu laktik aside parçalayarak, asitliği (gelişen asitlik) yükseltebilmektedir [36]. Çiğ sütün pH’1 6.8 'den yüksek ölçüldügünde hayvanın mastisis hastalığı geçirdiği ya da sütün asitliğini maskelemek amaciyla içerisine kostik olarak bilinen sodyum hidroksit katılarak tağşiş yapıldığı düşünülebilmektedir. pH'1 6.5'dan düşük olan sütlerin ise ağız sütü olduğu ya da sütte asitlik artışından dolayı kesilme olabileceği öngörülmektedir. Dolayısıyla pH aç1sindan sorunlu sütlerin işletmeye kabul edilmemesi gerekmektedir [37]. 
pH'ın süt tazeliğinin bir göstergesi olarak kullanılmasıyla ilgili yapılan bir çalışmada modern bir analitik araç olarak elektronik dil (e-dil) geliştirilmiştir. E-dil, sıvı veya katı numunelerin tadını ölçen ve karşılaştıran bir sensör sistemidir. İnsan tat sistemi, tat reseptörleri olarak hareket eden kimyasal sensörlerle taklit edilmekte ve potansiyometrik tepkinin bir fonksiyonu olarak elektrik sinyalleri üretilmektedir [38]. Tablo 3 'te bazı süt ürünlerinin sahip olduğu $\mathrm{pH}$ değerleri derlenmiştir.

Tablo 3. Bazı süt ürünlerin sahip olduğu pH değerleri [22, 39, 40, 41, 42].

\begin{tabular}{llll}
\hline Ürün & $\mathbf{p H}$ & Ürün & $\mathbf{p H}$ \\
\hline Bazı süt ürünleri & & & \\
\hline Krema (tatlı) & 6.5 & Tereyağ 1 & $6.1-6.4$ \\
Süt & $6.2-7.3$ & Yoğurt & $4.0-4.5$ \\
\hline Çeşitli peynirler & & & \\
\hline Beyaz peynir & 4.5 & Ezine peyniri & $4.77-5.06$ \\
Camembert peyniri & 7.44 & İsviçre gravyer peyniri & $5.1-6.6$ \\
Çedar peyniri & 5.9 & Krem peynir & 4.88 \\
Edam peyniri & 5.4 & Rokfor peyniri & $5.5-5.9$ \\
Erzincan tulum Peyniri & 5.30 & Süzme peynir & 5.0 \\
\hline
\end{tabular}

\subsubsection{Yumurta ürünleri ve pH Değerleri}

Yumurta ve ürünleri insanlar için çok iyi bir gıda olmasının yanı sıra, mikrobiyal gelişim için de iyi bir besin kaynağı olması nedeniyle oldukça riskli bir üründür. Yumurta akı $\mathrm{pH}$ değeri depolama başında yaklaşık 7.6 civarında iken, üç gün süreyle depolama sonucunda $\mathrm{pH}$ değeri 9.6 civarına yükselmektedir. Fakat taze yumurta sarısının $\mathrm{pH}$ değeri yaklaşık olarak 6.8 civarındadır [43]. Günümüzde endüstriyel birçok üründe de hammadde olarak kullanılan yumurta ve ürünlerinde mikrobiyal gelişimin ve depolama güvenliğinin kontrolü için $\mathrm{pH}$ değerinin kontrol edilmesi önemli bir basamaktır. Tablo 4 'te bazı firınc1l1k ürünlerin sahip olduğu $\mathrm{pH}$ değerleri belirtilmiştir. 
Tablo 4. Bazı firıncılık ürünlerin sahip olduğu pH değerleri [22, 43].

\begin{tabular}{llll}
\hline Ürün & $\mathbf{p H}$ & Ürün & $\mathbf{p H}$ \\
\hline Yumurta beyazı & $7.0-9.0$ & Yumurta sarıs1 & $6.4-6.8$ \\
Yumurta beyazı tozu & $6.5-7.5$ & Yumurta (tümü) tozu & $7.1-7.9$ \\
\hline
\end{tabular}

\subsection{Fermente Ürünler ve pH Değerleri}

Fermente ürünlerin $\mathrm{pH}$ değeri fermantasyon prosesinde hem enzimlerin hem de mikrobiyal (laktik asit bakterileri vb.) faaliyetlerin düzenli yürütülmesi için oldukça önemlidir. Ürün veriminin artırılması için, $\mathrm{pH}$ 'ın optimum bir değerde tutulması ve proses süresince kontrol edilmesi gerekmektedir $[6,20,44]$. Fermente et ve süt ürünleri, kendi grupları içerisinde bahsedildiği için ayrıca bu bölümde yer verilmemiştir. Tablo 5'te bazı fermente ürünlerin $\mathrm{pH}$ değerleri verilmiştir.

Tablo 5. Çeşitli fermente ürünlerin sahip olduğu $\mathrm{pH}$ değerleri $[22,45,46$, $47,48,49,50]$.

\begin{tabular}{llll}
\hline Ürün & $\mathbf{p H}$ & Ürün & $\mathbf{p H}$ \\
\hline Boza & $3.16-4.02$ & Şalgam & $3.3-3.8$ \\
Hardaliye & $3.54-4.33$ & Şarap & $2.0-3.8$ \\
Kefir & $4.2-4.6$ & Tarhana & $3.8-4.2$ \\
Sirke & $2.0-3.4$ & Turşu & $3.91-4.11$ \\
\hline
\end{tabular}

\subsection{Fırıncılık ürünleri ve pH Değerleri}

Fırıncılık ürünlerinde $\mathrm{pH}$ ölçümü genellikle hamur kabarmasını kontrol etmek için kullanılmaktadır. Genel olarak hamurdaki yüksek pH değerleri, pişmiş ürünlerde hacim kaybına ve hoş olmayan katılığa neden olmaktadır. pH çok düşükse, bisküvilerde parçalanma görülmektedir. $\mathrm{pH}$ 7.0-8.0 arası değerler ideal olarak kabul edilmektedir [6]. Özellikle ekşi hamur ürünlerde nişastanın glikozidik bağları, yüksek 
pH'da stabil iken, düşük pH'da hidrolize olmaktadırlar. Ekşi hamurun düşük $\mathrm{pH}$ değeri, nişasta retrogradasyonunun düşürülmesini sağlamaktadır [51]. Fırıncılık ürünlerinde $\mathrm{pH}$ 'ın izlenmesi, kaliteli ürün standardizasyonuna yardımcı olmaktadır. Piyasada bu amaçla çeşitli $\mathrm{pH}$ metreler (esnek malzemeler için penetrasyon elektrotlu $\mathrm{pH}$ metreler gibi) kullanılmaktadır [6]. Bazı hayvansal ürünlerin sahip olduğu pH değerleri Tablo 6'da verilmiştir.

Tablo 6. Bazı firıncılık ürünlerin sahip olduğu pH değerleri [22, 52, 53].

\begin{tabular}{llll}
\hline Ürün & $\mathbf{p H}$ & Ürün & $\mathbf{p H}$ \\
\hline Bisküvi & $7.1-7.3$ & Ekler & $4.4-4.5$ \\
Buğday unu & $6.0-6.3$ & Ekşi ekmek & 5.04 \\
Ekmek & $5.3-5.8$ & Kek & $6.26-6.80$ \\
\hline
\end{tabular}

\section{5. Çeşitli ürünler ve pH}

Yukarıda bahsedilen sınıfların dışında kalan bazı ürünlerin sahip olduğu pH değerleri Tablo 7'de özetlenmiştir.

Tablo 7. Çeşitli ürünlerin sahip olduğu pH değerleri [22].

\begin{tabular}{llll}
\hline Ürün & $\mathbf{p H}$ & Ürün & $\mathbf{p H}$ \\
\hline Bal & 3.9 & Misır nişastası & $4.0-7.0$ \\
Havyar & 5.4 & Misır şurubu & 5.0 \\
Kakao tozu & 6.3 & Pekmez & $5.0-5.5$ \\
Kuru üzüm & $3.8-4.0$ & Reçeller / Jöleler & $3.1-3.5$ \\
Maya & $3.0-3.5$ & Şeker & $5.0-6.0$ \\
Mayonez & $4.2-4.5$ & Zencefil gazozu & $2.0-4.0$ \\
\hline
\end{tabular}




\section{Mevzuat ve Standartlar Açısından pH Değerleri}

Gıdaların, mevzuat (TGK: Türk Gıda Kodeksi) ya da standartlara (TS: Türk Standardı) uygunluğunun tespitinde de $\mathrm{pH}$ ölçümünden yararlanılmaktadır. pH değeri, hammadde, yarı mamül ya da son ürün kalite kontrolü ve ürün mikrobiyal güvenliği için kullanılan parametrelerden biridir. Tablo 8'de mevzuat ve standartlar açısından, kalite kriteri olarak pH ölçümünün yapılması gereken ürünler verilmiştir.

$\mathrm{pH}$ değeri, turşu, meyve suyu veya peynir gibi şarküteri ürünlerinin olgunlaşma derecesi ve özellikle fermantasyon prosesinde hem enzimlerin hem de mikrobiyal faaliyetlerin düzenli yürütülmesi için oldukça önemlidir. Proses veriminin artırılması için, $\mathrm{pH}$ 'ın optimum bir değerde tutularak proses boyunca kontrol edilmesi gerekmektedir [6, $20,44,83]$.

Gıdaların renk, aroma (tat, koku) ve yapısal özellikleri pH'a bağlı olarak değişebilmektedir [20]. Gıda ürünlerinin dokusu, tüketicinin kabulünü etkilediği için en önemli kalite özelliklerinden biridir. Sebzelerde ve meyvelerde, doku genellikle hücre duvarı yapısı ve bileşimi, aynı zamanda hücre morfolojisi, boyutu, şekli, paketleme, içerik ve turgor gibi diğer faktörlerle de ilgilidir. Isıl işlem pektik polisakkaritlerde belirgin bir bozulmaya sebep olarak, hücreler arası yapışmanın azalmasına ve $\mathrm{pH} 4.5$ 'da artan yumuşamaya neden olmaktadır [84]. Et ve balığın dokusu ise, glikoliz oranı, ölüm sonrası sıcaklık düşüşü ve kaslardaki nihai $\mathrm{pH}$ ile ilişkilidir $[1,85]$. Tablo 8'de mevzuat ve standartlar açısından, kalite kriteri olarak pH ölçümünün yapılması gereken ürünler listelenmiştir. 
Tablo 8. Mevzuat ve standartlar açısından, kalite kriteri olarak pH ölçümünün yapılması gereken ürünler

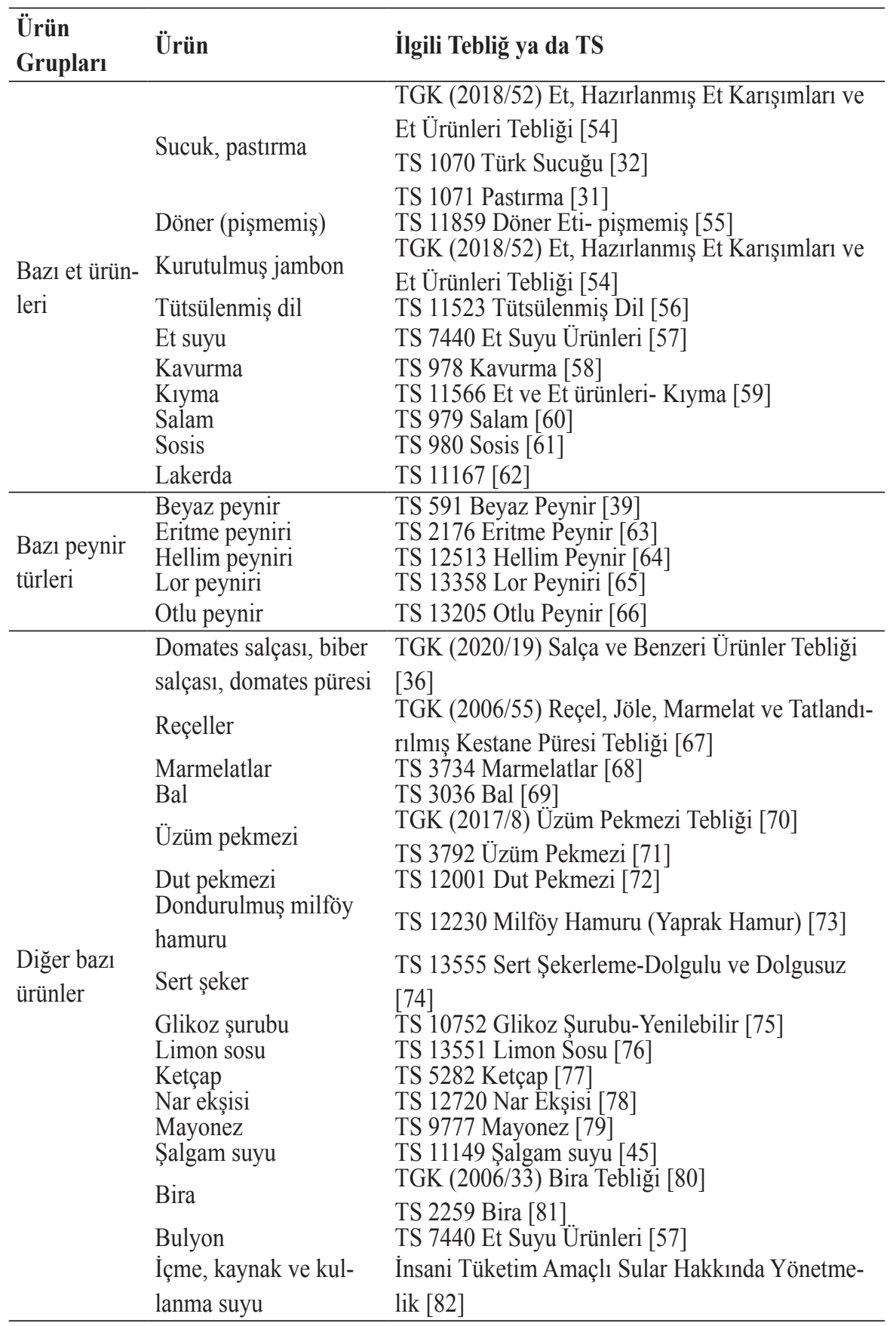


$\mathrm{pH}$ değeri meyvelerin, sebzelerin ve etlerin renginden sorumlu pigmentler (örneğin klorofil, karotenoidler, antosiyaninler, miyoglobin vb.) üzerinde önemli bir etkiye sahiptir. İşlenmiş meyve ve sebzelerin renk bileşikleri, mikroorganizma varlığ 1 ve enzimlerin inaktivasyonu veya etkisizliği nedeniyle işleme sırasında değişebilmekte, bu durumda gidada istenmeyen kimyasal reaksiyonlara (hem enzimatik hem de enzimatik olmayan) neden olabilmektedir [1, 86, 87].

Koruyucu katk1 maddeleri kullanımı, radyasyon, sterilizasyon ya da pastörizasyon gibi gıda muhafaza işlemlerinde $\mathrm{pH}$ kontrolü önemli bir kriterdir. Örneğin pH'1 5.8'den düşük olan sütlere pastörizasyon işlemi uygulanmamakta, bu sütler hammadde olarak işletmeye alınmamaktadır. Ayrıca, konserve yapma prosesinde, asitlik arttırılırsa uygulanacak sicaklık derecesi ve işlem süresinin azaltılabilmesi mümkündür [20]. Gıdanın yüksek basınçla işlenmesi sırasında pH değeri denatürasyon, jelleşme, enzimatik aktiviteler, mikroorganizma veya sporların büyümesi ya da ölümü ve kimyasal reaksiyonlar gibi birçok işlemi etkilemektedir [88].

Konserve ürünlerde $\mathrm{pH}$ değeri oldukça önemlidir. "Düşük asitli" bir gıda, pH değeri 4.6' dan yüksek olan bir gıda olarak tanımlanırken, "yüksek asitli" bir gida ise $\mathrm{pH}$ değeri 4.6 veya daha düşük olan bir gida olarak kabul edilmektedir. Bu değer, patojen bir bakteri olan Clostridium botulinum ve sporları nedeniyle kritiktir. Uygun şekilde işlenmemiş bir gıda, C. botulinum sporları için ideal bir ortam sağlayabilmektedir. Bir konserve gıda ürününün kesin işlem süresi gıdanın pH'1 dışında, ürünün viskozitesi ve boyutu, ambalaj boyutları ve pişirme ortamının sıcaklığı gibi birkaç faktöre bağlıdır [16, 22].

G1daların besin değerinin incelenmesinde de $\mathrm{pH}$ ölçümünün yapıldığı çalışmalar mevcuttur. Wechtersbach ve ark. [89] tarafindan yapılan çalışmada, önemli bir besin öğesi olan askorbik asidin ( $\mathrm{C}$ vitamini) $\mathrm{pH}$ 2.0-4.0 değerleri arasında kararlı olduğu, ancak pH 4.01'den daha yüksek değerlere çıkıldığında ise askorbik asidin, geri dönüşümsüz olarak ve vitamin aktivitesi göstermeyen 2,3,-diketo-L-gulonik aside dönüştüğü belirtilmektedir. Yukarıda bahsedilen ürünlerin dışında, 
gıda yetiştirme ya da temizleme amacıyla kullanılan maddelerin pH'1 da önemlidir. Örneğin balıkçılık sularında $\mathrm{pH}$ önemli bir parametredir. Suyun pH değeri, bu suyun balıklar için uygun olup olmadığını göstermektedir [90]. Bu gösterge, büyük ölçüde pH'a bağlı olan amonyum/amonyak dengesinde öne çıkmaktadır. Amonyak $\left(\mathrm{NH}_{3}\right)$ balıklar için oldukça zehirlidir. Aksine, amonyum $\left(\mathrm{NH}_{4}^{+}\right)$nispeten zararsızdir. $\mathrm{pH} 6.0$ iken suda tehlikeli amonyak yerine sadece amonyum bulunurken, $\mathrm{pH}$ 9.0'da, amonyak konsantrasyonunun \%25 olduğu belirtilmektedir [6]. Başka bir örnek olarak ise, g1da sektöründe kullanılan dezenfektanların da $\mathrm{pH}$ değeri ve içerdiği oksidan maddelerin, gıdanın besin değerlerini etkileyebilmesi verilebilir. Dezenfeksiyon sırasında özellikle C vitamini (L-askorbik asit) sadece $\mathrm{pH}$ 2.0-4.0 değerleri arasında kararlıdır. $\mathrm{Bu} \mathrm{pH}$ değerleri dışında olan dezenfektanlar, $\mathrm{C}$ vitamini kaybına neden olabilmektedir. Bu nedenle gidaya uygun dezenfektan seçimi yapılırken, mutlaka $\mathrm{pH}$ değeri dikkate alınmalıdır [91].

\section{Sonuç}

Gıdalar açısından pH değeri oldukça önemli bir kavramdır. Gıda güvenliği ve kalitesinin göstergelerinden biri olmasının yanı sıra, belli başlı gıda ürünleri için mevzuata ve ilgili standartlara uygunluğunun da ölçütlerinden biridir. Bu çalışmada değişik ürün gruplarında yer alan gıdaların $\mathrm{pH}$ değerleri, kalite ve gıda güvenliği açısından bu değerlerin önemi, mevzuat ve ürün standartları açısından limit $\mathrm{pH}$ değerleri incelenerek derlenmiştir. Elde edilen sonuçlara göre piyasada hali hazırda çeşitli uygulamalar için farklı $\mathrm{pH}$ metreler mevcut olsa da, her geçen gün gelişen gida sektöründe, modern ve karmaşık gıda üretim tekniklerinde kullanıma uygun ve ölçüm hassasiyeti yüksek olan, pratik yeni cihazlar geliştirilmesi ihtiyacı olduğu sonucuna varılmıştır. Ayrıca pH değeri ve gıdaların raf ömrü arasındaki ilişki üzerinde yapılan çalışma sayısının artması ve birçok ürün için modern $\mathrm{pH}$ sensörlerinin geliştirilmesinin, günümüz üreticisinin ilgisini çekeceği ve beklentisini karşılayacağı, depolama ve nakliye aşamalarında gıda 
güvenliği açısından kritik bir gösterge olarak değerlendirileceği öngörülmektedir. Gıda-pH ilişkisinin değişik açılardan incelenmesi temelinde hazırlanan bu çalışma ile gıda sektörüne ve literatüre bilgi anlamında katkı sağlandığı düşünülmektedir.

\section{Kaynaklar}

[1] Andres-Bello, A., Barreto-Palacios, V., Garcia-Segovia, P., Mir-Bel, J. ve Martinez-Monzo, J., Effect of $\mathrm{pH}$ on color and texture of food products, Food Engineering Reviews, 5(3), (2013), 158-170.

[2] Crespo, G.A., Afshar, M.G. ve Bakker, E., Direct detection of acidity, alkalinity, and $\mathrm{pH}$ with membrane electrodes, Analytical Chemistry, 84, (2012), 10165-10169.

[3] Güler, Ç. Su Kalitesi. Sağlık Bakanlığı Çevre Sağlığı Temel Kaynak Dizisi, Birinci Bask1, Ankara, (1997). 43, 85s. https://sbu.saglik.gov.tr/Ekutuphane/kitaplar/css43.pdf (Erişim Tarihi: 07.09.2020).

[4] Tyl, C., Sadler ve G.D., pH and Titratable Acidity. Nielsen's. (Eds) Food Analysis. Food Science Text Series. Springer, (2017).

[5] Ertürün, H.E.K., Titrasyon asitliğinin tayini için zofenopril kalsiyuma dayanan pH elektrot yapımı. Gida, 42 (3), (2017), 211-218.

[6] Testo, Guide to $\mathrm{pH}$ measurement engineering. (2004). http://pst-ir.com/wp-content/uploads/2013/11/ https__ex.testo_.de_pdf_download.php_filepublications_Publications_EN_02-FIELD-MANUALS_Guide-to-.pdf (Erişim tarihi: 20.07.2020).

[7] Webster, D., pH - Principles and Measurement. Encyplopedia of Food Science, Food Technology and Nutrition. Second Edition, Academic Press, (2003), 4501-4507p.

[8] Otterson, D.W. , Tech talk: (11) pH measurement and control basics. Measurement and Control -London- Institute of Measurement and Control, 48(10), (2015), 309-312.

[9] Vijayakumar, P. ve Adedeji, A., Measuring the $\mathrm{pH}$ of food products. (2017). https://www.researchgate.net/publication/330601448_Measuring_the_pH_of_ Food_Products (Erişim tarihi: 06.09.2020).

[10] Chaminda, P., Samaranayake, C.P. ve Sastry, S.K., In-situ pH measurement of selected liquid foods under high pressure. Innovative Food Science and Emerging Technologies, 17, (2012), 22-26.

[11] Gaml, Ö.G., Laboratuar Teknikleri ve Temel Gıda Analizleri. 2.Bask1, (2015), Dora Yayıncilık, Bursa. 
[12] Vivaldi, F., Santalucia, D., Poma, N., Bonini, A., Salvo, P., Noce, L.D., Melai, B., Kirchhain, A. ve Francesco, F.D., A voltametric $\mathrm{pH}$ sensor for food and biological matrices. Sensors and Actuators B: Chemical, 322, (2020), 128650.

[13] Jiang, Y., Liu, X., Huang, X., Feng, H., Zhang, Q. Ve Yu, H., High-sensitivity potentiometric $65-\mathrm{nm}$ cmos ISFET sensor for rapid E. coli screening. IEEE Transactions On Biomedical Circuits And Systems, 12(2), (2018), 402-415.

[14] Stippl, V. M., Delgado, A. ve Becker, T.M., Development of a method for the optical in situ determination of $\mathrm{pH}$ value during high-pressure treatment of fluid food. Innovative Food Science and Emerging Technologies, 5, (2004), 285-292.

[15] https://www.mindbodygreen.com/0-5165/Alkaline-Acidic-Foods-Chart-The-pH-Spectrum.html (Erişim Tarihi: 12.09.2020).

[16] http://eds.b.ebscohost.com/eds/pdfviewer/pdfviewer?vid=3\&sid=bbc19f6f-2193-442e-a0d0-83f932aea59d\%40pdc-v-sessmgr02 (Erişim tarihi: 20.07.2020).

[17] Kuswandi, B. ve Murdyaningsih, E.A., Simple on package indicator label for monitoring of grape ripening process using colorimetric $\mathrm{pH}$ sensor. Journal of Food Measurement and Characterization, 11, (2017), 2180-2194

[18] Islam, M.D.S., Hasan, M.D.M., Khan, A.A.S., Bakar, M.A., A simple system to detect and measure formalin in fruit by using conductivity, $\mathrm{pH}$ and capacitance measurement. Carpathian Journal of Food Science and Technology, 11(3), (2019) 86-93.

[19] Ahmad, N.A., Heng, L.Y., Zaid, M.H.M., Hanifah, S.A. ve Salam, F.A., colorimetric $\mathrm{pH}$ sensor based on Clitoria $\mathrm{sp}$ and Brassica sp for monitoring of food spoilage using chromametry. Sensors, 19, (2019), 4813.

[20] https://www.foodelphi.com/tag/gidalarda-ph-ve-toplam-asitlik-tayini/. (Erişim Tarihi: 06.09.2020).

[21] Çopur, U., Bir jelleşme maddesi olarak pektin. Gıda, 13(4), (1988), 253-257.

[22] McGlynn, W. The importance of food $\mathrm{pH}$ in commercial canning operations. Oklahama State University, Food Technology Fact Sheet, (2003), FAPC-118. https://shareok.org/bitstream/handle/11244/50205/oksd_fapc_118_2010-07. pdf? sequence=1 (Erişim Tarihi: 18.08.2020).

[23] Ergezer, H. Ve Serdaroğlu, M., Et ve et ürünlerinde su tutma kapasitesi ve ölçüm yöntemleri. Türkiye 10. G1da Kongresi, May 21-23, 2008, Erzurum, Türkiye, Bildiriler Kitab1, 493-496s.

[24] Lonergan E.H. ve Lonergan S.M., Mechanisms of water holding capacity of meat. Meat Science, 71, (2005), 194-204.

[25] Kadıŏlu, P., Karakaya, M., Unal, K. ve Babaoğlu, A. S., Technological and textural properties of spent chicken breast, drumstick and thigh meats as affected by marinating with pineapple fruit juice. British Poultry Science, 60(4), (2019), 381-387. 
[26] Watanabe, A., Daly, C.C. ve Devine, C.E., The effects of the ultimate pH of meat on tenderness changes during ageing. Meat Science, 42(1), (1996), 67-78.

[27] Rao, M.W., Gault, N.F.S. ve Kennedy, S., Changes in the ultrastructure of beef muscle as influenced by acidic conditions below the ultimate $\mathrm{pH}$. Food Microstructure, 8, (1989), 115-124.

[28] Lawrie, R.A., Meat Science, Pergamon Press, New York, (1991).

[29] Abdalla, H., Alı, N., Siddig, F. ve Alı, S., Improving tenderness of spent layer hens meat using papaya leaves (Carica papaya). Pakistan Veterinary Journal, 33(1), (2013), 73-76.

[30] Çarbuğa, Ü., Marinasyon işlemlerinin sı̆̆ır eti üzerindeki kimyasal, duyusal ve tekstürel etkilerinin belirlenmesi. Yüksek Lisans Tezi, Necmettin Erbakan Üniversitesi, Fen Bilimleri Enstitüsü, Konya, (2019).

[31] TS 1071 Pastırma Standardı, Türk Standartları Enstitüsü, Ankara, (2002).

[32] TS 1070 Türk Sucuğu Standardı, Türk Standartları Enstitüsü, Ankara, (2012).

[33] Kadak, A.E. ve Çelik, M., Kitosan eklenmiş hamsi marinatlarının soğuk depolanmasında meydana gelen fiziksel ve duyusal değişimler. Alınteri Zirai Bilimler Dergisi, 28(B), (2015), 33-44.

[34] Külcü, D.B., Farklı sıcaklıklarda muhafaza edilen palamut (Sarda sarda) balığının bazı kimyasal kalite niteliklerinin belirlenmesi. Sakarya Üniversitesi Fen Bilimleri Enstitüsü Dergisi, 21(3), (2017), 403-410.

[35] Küçük, S.C. ve Yıbar, A.,Çiğ süt ve pastörize süt tüketiminin halk sağlığı üzerine etkileri. Food and Health, 5(3), (2019), 197-204.

[36] Türk Gıda Kodeksi, Salça ve Benzeri Ürünler Tebliği, (2020).

[37] Ertem, H. ve Çakmakçı, S., Erzurum'da açık olarak satışa sunulan çiğ sütlerin bazı hileler ve kalite özellikleri yönünden araştırılması - ilgili tebliğ ile karşılaştırılması. Atatürk Üniversitesi Ziraat Fakültesi Dergisi, 50(3), (2019), 255-262.

[38] Tang, T.B. ve Zulkafli, M.S., Electronic tongue for fresh milk assessment a revisit of using ph as indicator. IEEE International Conference on Circuits and Systems (ICCAS), Sept 2013, Book of Proceedings, (2013), 167-171p.

[39] TS 591 Beyaz Peynir Standard1, Türk Standartları Enstitüsü, Ankara, (2013).

[40] Tekinşen, K.K. ve Akar, D., Erzincan tulum peyniri. Atatürk Üniversitesi Veteriner Bilimleri Dergisi, 12(2), (2017), 218-226.

[41] Uymaz, B., Akçelik, N. ve Yüksel, Z., Physicochemical and microbiological characterization of protected designation of origin Ezine cheese: assessment of non-starter lactic acid bacterial diversity with antimicrobial activity. Food Science of Animal Resources, 39(5), (2019), 804-819.

[42] https://www.ggd.org.tr/sss2.php?bolum=248\#: :text=da\%20neden\%20olmaktad $\%$ C4\%B1r.-,S\%C3\%BCt\%20ve\%20yo $\%$ C4\%9Furdun $\% 20$ ph $\% 20 \mathrm{de} \%$ C4\%9Feri\%20nedir\%3F,4\%2D4\%2C5\%20aras\%C4\%B1ndad\%C4\%B1r (Erişim Tarihi: 02.20.2020). 
[43] https://www.diatek.com.tr/Makale-Yontem/Mikrobiyolojik-Analiz/Yumurtada-Gorulen-bozulmalar_3425.htm\#: :text=Yumurta\%20ak\%C4\%B1n\%C4\%B1n\%20pH's\%C4\%B1\%20ba\%C5\%9Flang\%C4\%B1\%C3\%A 7ta,i\%C3\%A7in\%20m\%C3\%BCkemmel\%20bir\%20besi\%20 ortam $\% \mathrm{C} 4 \% \mathrm{~B} 1 \mathrm{~d} \% \mathrm{C} 4 \% \mathrm{~B} 1 \mathrm{r}$. (Erişim Tarihi: 02.10.2020).

[44] Bühler, H., Ingold, W. Ve Uyanık, A., Fermantasyonda pH ve oksijen ölçümü. Gida, 6(1-2), (2001), 26-32.

[45] TS 11149 Şalgam Suyu Standardı, Türk Standartları Enstitüsü, Ankara, (2003).

[46] Karagözlü, C. Fermente süt içeceği: kefir. Apelasyon, Aralık, (2015). 25. http://apelasyon.com/Yazi/367-fermente-sut-icecegi-kefir. (Erişim Tarihi: 10.10.2020).

[47] Levent, H. ve Cavuldak, Ö.A., Geleneksel fermente bir içecek: boza. Akademik Gida, 15(3), (2017), 300-307.

[48] Coşkun, F., Arıcı, M., Gülcü, M., Çelikyurt, G. ve Mırık, M., Physicochemi$\mathrm{cal}$, functional and microbiological properties of hardaliye beverages produced from different grapes. Tarım Bilimleri Dergisi - Journal of Agricultural Sciences, 24, (2018), 278-285.

[49] Hendek Ertop, M., ve Atasoy, R., Farklı tahıl ve bakliyat unları ile üretilen tarhanaların fizikokimyasal, reolojik ve duyusal nitelikleri. Gıda, 44(5), (2019), 781-793.

[50] Tokatl1, M., Elmacı, S.M., Arslankoz İşleyen, N. ve Özçelik, F., Seçilmiş endojen laktik starter kültürler ile turşu üretimi. Gıda, 44(4), (2019), 742-757.

[51] Kotancılar, H.G., Karaoğlu, M.M., Gerçekaslan, K.E. ve Uysal, P., Ekşi hamur katkısının beyaz tava ekmeğinin bayatlaması üzerine etkisi. Atatürk Üniversitesi Ziraat Fakültesi Dergisi, 37(1), (2006), 103-110.

[52] Tuncel N. B. ve Demirci M., Farklı sicaklık derecelerinde depolanan hamurların kek kalitesi üzerine etkilerinin araştırılması. Türkiye 9. Gıda Kongresi, (2006, Mayıs), Bolu, Türkiye, Bildiriler Kitabı, 521-524s.

[53] Hendek Ertop, M., Ekşi hamur formül optimizasyonunun ekmeğin aromatik profili, biyoaktif nitelikleri ve raf ömrü üzerine etkileri, Doktora Tezi, Erciyes Üniversitesi, Fen Bilimleri Enstitüsü, Kayseri, (2014).

[54] Türk Gıda Kodeksi, Et, Hazırlanmış Et Karışımları ve Et Ürünleri Tebliği, (2018).

[55] TS 11859 Döner Eti (Pişmemiş) Standardı, Türk Standartları Enstitüsü, Ankara, (2016).

[56] TS 11523 Tütsülenmiş Dil Standardı, Türk Standartları Enstitüsü, Ankara, (1995).

[57] TS 7440 Et Suyu Ürünleri Standardı, Türk Standartları Enstitüsü, Ankara, (2002). 
[58] TS 978 Kavurma Standardı, Türk Standartları Enstitüsü, Ankara, (2016).

[59] TS 11566 Et ve Et ürünleri- Kıyma Standard1, Türk Standartları Enstitüsü, Ankara, (2016).

[60] TS 979 Salam Standardı, Türk Standartları Enstitüsü, Ankara, (2017).

[61] TS 980 Sosis Standard1, Türk Standartları Enstitüsü, Ankara, (2016).

[62] TS 11167 Lakerda Standard1, Türk Standartları Enstitüsü, Ankara, (1993).

[63] TS 2176 Eritme Peyniri Standard1, Türk Standartları Enstitüsü, Ankara, (2011).

[64] TS 12513 Hellim Peyniri Standard, Türk Standartları Enstitüsü, Ankara, (2018).

[65] TS 13358 Lor Peyniri Standard1, Türk Standartları Enstitüsü, Ankara, (2016).

[66] TS 13205 Otlu Peynir Standardı, Türk Standartları Enstitüsü, Ankara, (2016).

[67] Türk Gıda Kodeksi, Reçel, Jöle, Marmelat ve Tatlandırılmış Kestane Püresi Tebliği, (2006).

[68] TS 3734 Marmelatlar Standardı, Türk Standartları Enstitüsü, Ankara, (2013).

[69] TS 3036 Bal Standardı, Türk Standartları Enstitüsü, Ankara, (2010).

[70] Türk Gıda Kodeksi, Üzüm Pekmezi Tebliği, (2017).

[71] TS 3792 Üzüm Pekmezi Standard1, Türk Standartları Enstitüsü, Ankara, (2008).

[72] TS 12001 Dut Pekmezi Standardı, Türk Standartları Enstitüsü, Ankara, (1996).

[73] TS 12230 Milföy Hamuru (Yaprak hamur) Standard1, Türk Standartları Enstitüsü, Ankara, (2013).

[74] TS 13555 Sert şekerleme (Dolgulu ve dolgusuz) Standardı, Türk Standartları Enstitüsü, Ankara, (2013).

[75] TS 10752 Glukoz şurubu (Yenilebilir) Standardı, Türk Standartları Enstitüsü, Ankara, (2003).

[76] TS 13551 Limon Sosu Standard1, Türk Standartları Enstitüsü, Ankara, (2013).

[77] TS 5282 Ketçap Standard1, Türk Standartları Enstitüsü, Ankara, (2003).

[78] TS 12720 Nar Ekşisi Standardı, Türk Standartları Enstitüsü, Ankara, (2016).

[79] TS 9777 Mayonez Standardı, Türk Standartları Enstitüsü, Ankara, (1992).

[80] Türk Gıda Kodeksi, Bira Tebliği, (2006).

[81] TS 2259 Bira Standardı, Türk Standartları Enstitüsü, Ankara, (2012).

[82] İnsani Tüketim Amaçlı Sular Hakkında Yönetmelik, Ankara, (2016).

[83] Gallo, M., Nigro, F., Passannanti, F., Nanayakkara, M., Lania, G., Parisi, F., Salameh, D., Budelli, A., Barone, M.V. ve Nigro, R., Effect of pH control during rice fermentation in preventing a gliadinentrance in epithelial cells. International Journal of Food Sciences and Nutrition, 70(8), (2019), 31-43.

[84] Harker, F.R., Redgwell, R.J., Hallett, I.C. ve Murray, S.H., Texture of fresh fruit. Horticultural Reviews, 20, (1997), 121-124. 
[85] Gonçalves, A.A, The $\mathrm{pH}$ of the seafood meat: a problem that deserves to be clarified. MOJ Food Processing and Technology, 4(1), (2017), 00081.

[86] Tijkens, L.M.M., Barringer, S.A. ve Biekman, E.S.A, Modelling the effect of $\mathrm{pH}$ on the color degradation of blanched broccoli. Innovative Food Science and Emerging Technologies, 2, (2001), 315-322.

[87] Wahyuningsih, S., Wulandari, L., Wartono, M.W., Munawaroh, H. ve Ramelan, A.H., The effect of $\mathrm{pH}$ and color stability of anthocyanin on food colorant. IOP Conference Series: Materials Science and Engineering, International Conference on Food Science and Engineering, (2016, October 18-19), Srukarta, Indonesia,193, 012047.

[88] Stippl, V. M., Delgado, A. ve Becker, T.M., Optical method for the in-situ measurement of the $\mathrm{pH}$-value during high pressure treatment of foods. International Journal of High Pressure Research, 22(3-4), (2002), 757-761.

[89] Wechtersbach, L., Polak, T., Ulrih, N.P. ve Cigić, B., Stability and transformation of products formed from dimeric dehydroascorbic acid at low $\mathrm{pH}$. Food Chemistry, 129(3), (2011), 965-973.

[90] Boyd C.E., Carbon Dioxide, pH, and Alkalinity. Water Quality: An Introduction. Springer, Auburn, US, (2015).

[91] Türközü, D. ve Karabudak, E., Marulların C vitaminin içerikleri üzerine gıda dezenfektanlarının etkisi. Beslenme ve Diyet Dergisi, 42(1), (2014), 43-51. 